\title{
Peran Dewan Pengupahan Dalam Rangka Penentuan Upah Minimum Kabupaten ( UMK ) Dan Upah Minimum Sektoral Kabupaten ( UMSK ) Di Kabupaten Oku Timur
}

\author{
Winda Feriyana \\ Program Studi Manajemen STIE Trisna Negara Belitang
}

\begin{abstract}
ABSTRAK
Upah merupakan salah satu faktor pertimbangan seseorang untuk bekerja. Seorang tenaga kerja memiliki nilai tawar yang dapat meningkat ditentukan oleh keterampilan dan pengalaman. Adapun pengguna yang membutuhkan tenaga tersebut bersedia meningkatkan upah selain ditentukan oleh harga pasar juga ditentukan oleh produktivitas tenaga tersebut. Peran dewan pengupahan pada tingkat nasional, provinsi atau kabupaten / kota diharapkan dapat menghasilkan kesepakatan - kesepakatan dalam meningkatkan pertumbuhan ekonomi, khususnya menjadi jembatan yang baik bagi pekerja dan pengusaha sebagai pemberi kerja dengan memberikan saran dan pertimbangan kepada gubernur / bupati dalam menetapkan upah minimum.
\end{abstract}

Kata kunci : upah, upah minimum, dewan pengupahan

\section{PENDAHULUAN}

Masalah upah merupakan salah satu faktor yang jadi pertimbangan seseorang untuk menawarkan jasanya untuk bekerja, dalam memutuskan untuk bekerja bukan saja pertimbangan besarnya upah yang akan diterima tetapi juga kompensasi non upah yang diberikan pengusaha, seperti diketahui bahwa Negara kita Indonesia terkenal dengan tenaga kerja yang murah dan jumlahnya yang sangat banyak.

Melihat fenomena ini maka terbentuklah dewan pengupahan yang secara yuridis berdasarkan Keputusan Presiden Republik Indonesia no. 107 Tahun 2007. Dewan pengupahan terbagi atas dewan pengupahan nasional, dewan pengupahan provinsi dan dewan pengupahan kabupaten / kota. Masing - masing tingkatan dewan pengupahan memiliki kewenangan.

Masing - masing dewan pengupahan merupakan manifestasi kepentingan bangsa dan Negara ini untuk mendorong adanya kesepakatan
- kesepakatan dalam menentukan arah dari (salah satu faktor) pertumbuhan ekonomi. Satu - satunya fungsi yang Nampak dari dewan pengupahan yaitu " Memberikan saran dan pertimbangan " khususnya untuk upah bagi pekerja.

Landasan hukum bagi dewan pengupahan yang utama adalah UU No. 13 Th. 2003 tentang ketenaga kerjaan. Turunan undang - undang ini secara spesifik mengatur mengenai dewan pengupahan adalah Keputusan Presiden 107 Th. 2004.

Menurut Keputusan Presiden RI No. 107 Th. 2004 Bab I Pasal I dewan pengupahan didefinisikan sebagai " suatu lembaga non struktural yang bersifat TRIPARTIT yang terdiri dari unsur Pemerintah, Pengusaha dan Pekerja yang dibentuk berdasarkan Keputusan Presiden yang dalam kerangka ini kewenangan dewan pengupahan murni berasal dari presiden sebagai kepala pemerintahan sehingga proses pembentukannya merupakan manifestasi hak prenogratif presiden. 


\section{TUGAS DAN WEWENANG DEWAN PENGUPAHAN}

Sesuai dengan pasal 98 UU No. 13 / 2003 menyatakan bahwa tugas dewan pengupahan yaitu untuk memberikan saran pertimbangan dan merumuskan kebijakan pengupahan yang akan ditetapkan pemerintah khususnya dibidang pengupahan.

Dewan pengupahan provinsi memiliki tugas untuk memberikan saran dan pertimbangan kepada gubernur dalam rangka penetapan upah minimum provinsi (UMP) dan upah minimum sektoral, tidak jauh beda dengan dewan pengupahan kabupaten / kota pada dasarnya juga memiliki ruang tugas yang sama dengan dewan pengupahan provinsi hanya saja ruang lingkupnya yang berbeda.

Dalam rangka menetapkan upah dewan pengupahan provinsi dan dewan pengupahan kabupaten / kota mempunyai wewenang yang spesial dikarenakan adanya PERMENAKERTRANS No. 13 Th. 2012 tentang Komponen Dan Pelaksanaan Tahapan Pencapaian Kebutuhan Hidup Layak yang mencantumkan hal - hal yang dapat dilakukan dewan pengupahan. Selain diatur dalam Keputusan presiden No. 107 Th. 2004 yakni bahwa dewan pengupahan provinsi dan kabupaten / kota dapat membentuk gugus tugas dalam komisi dan mengatur lebih lanjut tentang tata kerjanya.

PERMENAKERTRANS No. 13 Th. 2003 juga memberikan peluang kewenangan yaitu " Menetapkan kualitas dan spesifikasi tekhnis masing - masing komponen dan jenis KHL dan membentuk tim survey KHL " serta menetapkan nilai $\mathrm{KHL}$ ( Kebutuhan Hidup Layak ).

\section{Interpretasi Dari Pasal 3 Ayat ( 1 )} Dan ( 2 ) :

1. Nilai masing - masing komponen dan jenis KHL diperoleh melalui survey harga yang dilakukan secara berkala

2. Kualitas dan spesifikasi teknis masing - masing komponen dan jenis $\mathrm{KHL}$ sebagaimana dimaksud pada ayat ( 1$)$ disepakati sebelum survey dilaksanakan dan ditetapkan oleh ketua dewan pengupahan provinsi atau ketua dewan pengupahan kabupaten / kota.

\section{Upah Dan Upah Minimum}

Para pengusaha selalu berusaha mendapat keuntungan sebesar besarnya dengan menekan biaya berupa upah dan gaji seminimal mungkin karena faktor upah dan gaji merupakan faktor biaya bagi pengusaha. Untuk menentukan besarnya upah banyak cara atau system pemberian upah yang dapat diikuti.

Pemberian upah dipengaruhi oleh masalah persaingan di pasar tenaga kerja, pendidikan, keterampilan, perilaku karyawan dan pengalamnnya. Penetapan upah juga melihat kepada tingkat produktivitas, biaya hidup dan laba yang diperoleh pengusaha, ini semua dikemukakan oleh Buchari Alma (2002). Demikian juga halnya yang dinyatakan oleh Bruce $\mathrm{E}$. Kaufman dan Julit L. Hotchkins (2003) : "Wage Rate" Is Infinitive Obvious It Is The Price Of Labour Per Hour Of Work.

Sedangkan dalam teori ekonomi menurut Sadono Sukirno (2004) upah didefinisikan sebagai pembayaran yang diperoleh dari berbagai bentuk jasa yang disediakan dan diberikan oleh tenaga kerja kepada para pengusaha. 


\section{A. Jenis Upah}

1. Upah Uang

Diartikan sebagai jumlah uang yang diterima para pekerja dari para pengusaha sebagai pembayaran atas tenaga mental atau fisik para pekerja yang digunakan dalam proses produksi, Sadono Sukirno (2004)

2. Upah Riil

Adalah tingkat upah pekerja yang diukur dari sudut kemampuan upah tersebut untuk membeli barang - barang dan jasa - jasa yang diperlukan untuk memenuhi kebutuhan para pekerja.

\section{Teori Upah}

Ada 2 teori tentang upah (Buchari Alma, 2002)

1. Teori Tawar Menawar Menyatakan bahwa tingkat upah ditentukan oleh tawar menawar di pasaran tenaga kerja.

2. Teori Standar Hidup

Didasarkan atas keyakinan bahwa buruh harus dibayar secara layak agar dapat memenuhi kebutuhan standar hidupnya.

\section{B. Upah Minimum}

Upah Minimum adalah suatu standar minimum yang digunakan oleh para pengusaha atau pelaku industri untuk memberikan upah kepada pekerja didalam lingkungan usahanya (Nurlina Tarmizi, 2012).

Menurut peraturan menteri tenaga kerja dan transmigrasi pasal I No. I upah minimum adalah upah bulanan terendah yang terdiri atas upah pokok termasuk tunjangan tetap yang ditetapkan oleh gubernur sebagai jaring pengaman.
Sedangkan yang dimaksud dengan upah minimum sektoral kabupaten / kota (UMSK) adalah upah minimum yang berlaku secara sektoral di wilayah kabupaten / kota.

Upah minimum yang ditetapkan berdasarkan peraturan menteri No. I pasal I Ayat I Th. 1999 yaitu " Upah minimum dapat diatas atau dibawah upah pasar " tentu saja hal ini memunculkan konsekuensi yang berbeda. Disatu sisi dapat memunculkan pertambahan jumlah pengangguran, disisi lain dapat menimbulkan keuntungan berupa upah efisien (Efficience Wage).

Penentuan upah minimum didasarkan pada pertimbangan ;

a. Sebagai wujud pelaksanaan UUD 1945

b. Jejaring pengaman agar nilai upah tidak merosot dibawah kebutuhan hidup minimal.

c. Upaya pemerataan pendapatan dan proses pertumbuhan kelas menengah .

d. Kepastian hukum bagi perlindungan atas hak - hak dasar buruh dan keluarganya sebagai warga Negara Indonesia.

e. Merupakan indikator perkembangan ekonomi pendapatan perkapita.

Pernyataan ini muncul karena peraturan menteri No.1 pasal 1 ayat 1 Th. 1999 yang menyatakan bahwa " Upah minimum adalah upah bulanan terendah yang terdiri dari upah pokok (75\% dari upah pokok) ditambah tunjangan tetap (tidak termasuk tunjangan tidak tetap) dan berlaku bagi mereka yang lajang dan memiliki pengalaman kerja $0-1$ tahun.

Sedangkan menurut surat edaran menteri tenaga kerja No. SE - 07 / MEN / 1990 yang dimaksud dengan upah (gaji) pokok, tunjangan tetap dan tunjangan tidak tetap adalah : 
Upah Pokok :

Imbalan dasar yang dibayarkan kepada pekerja menurut tingkat atau jenis pekerjaan yang besarnya ditetapkan berdasarkan kesepakatan.

\section{Tunjangan Tetap :}

Tunjangan yang pembayarannya dilakukan secara teratur dan tidak dikaitkan dengan kehadiran atau pencapaian prestasi kerja.

Upah minimum provinsi dan kabupaten ditetapkan melalui keputusan gubernur atau bupati berdasarkan rekomendasi dari dewan pengupahan dan berlaku selama 1 tahun berjalan karena pemenuhan kebutuhan yang layak di setiap provinsi atau kabupaten berbeda beda.

\section{Komponen / Data Yang Menjadi Dasar Bagi Dewan Pengupahan Kabupaten OKU Timur Dalam Penentuan UMK Dan UMSK}

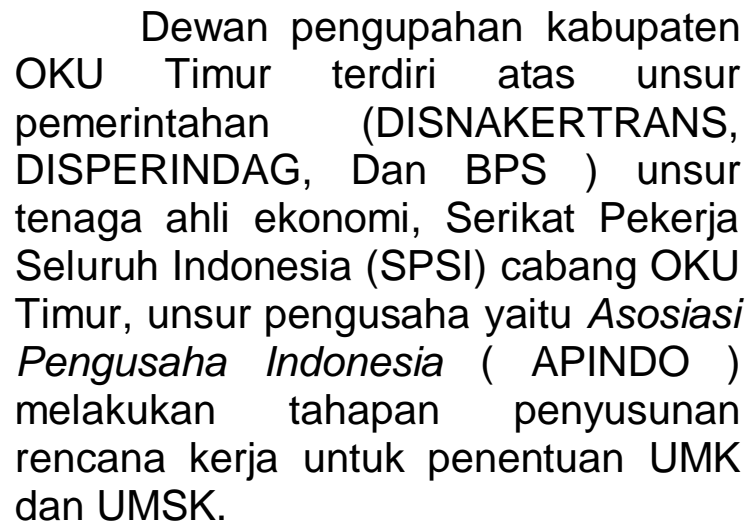
unsur - unsur atau data yang diperlukan sebagai dasar penyusunan UMK dan UMSK Kabupaten OKU Timur.

1. Data Upah minimum provinsi SUMSEL yang dijadikan dasar sebelum ditetapkannya UMK.

2. Data survey Komponen Hidup Layak (KHL) yang diartikan dalam peraturan menteri tenaga kerja dan transmigrasi nomor
13 pasal 1 tahun 2012 adalah standar kebutuhan seorang pekerja / buruh lajang untuk dapat hidup layak secara fisik untuk kebutuhan 1 (satu) bulan. Sedangkan komponen dan jenis kebutuhan diatur pada BAB II pasal 2.

3. Melakukan penelitian dan menghimpun data dan informasi sesuai dengan PERMENAKERTRANS No. 7 pasal 13 Th. 2013 yaitu mengenai :

1. a. Homogenitas perusahaan

b. Jumlah perusahaan

c. Jumlah tenaga kerja

d. Devisa yang dihasilkan

e. Nilai tambah yang dihasilkan

f. Kemampuan yang dihasilkan

g. Asosiasi perusahaan

h. Serikat pekerja / Serikat buruh terkait

2. Melakukan penelitian untuk menentukan sector unggulan yang selanjutnya disampaikan kepada Asosiasi perusahaan dan serikat pekerja / buruh di sektor yang bersangkutan untuk dirundingkan.

3. Besaran UMK dan atau UMSK yang disepakati oleh Asosiasi perusahaan dan serikat pekerja / serikat buruh di sektor yang bersangkutan.

4. Data inflasi

Arti inflasi seperti dikemukakan oleh Pratama Raharja dan Mandala Manurung (2008) diketahui perkembangan indeks harga konsumen / inflasi perkotaan provinsi Sumatera Selatan yang diketahui sampai bulan Januari 2018 sebesar $(0,88 \%)$ 
Jakarta ; PT. Raja Grafindo Persada.

\section{Pengantar}

Teori Mikro Ekonomi, Edisi ketiga, Jakarta ; PT. Raja Grafindo Persada.
Surat Edaran menteri tenaga Kerja Nomor : SE - 07 / MEN / 1990. Tentang Pengelompokan Upah.

Undang - Undang Republik Indonesia Nomor : 131 Tahun 2003, Ketenagakerjaan. 